\title{
Exogenous Application of L-Arginine Improves Protein Content and Increases Yield of Pereskia aculeata Mill. Grown in Soilless Media Container
}

\author{
Isabela Scavacini Freitas 1,*(D), Bruna Isadora Trennepohl ${ }^{2}$, Thiago Machado Silva Acioly ${ }^{2}$, \\ Vivyan Justi Conceição ${ }^{1}$, Simone Costa Mello ${ }^{1}$, Durval Dourado Neto ${ }^{1}$, Ricardo Alfredo Kluge ${ }^{2}$ \\ and Ricardo Antunes Azevedo ${ }^{3}$
}

check for updates

Citation: Freitas, I.S.; Trennepohl, B.I.; Acioly, T.M.S.; Conceição, V.J.; Mello, S.C.; Dourado Neto, D.; Kluge, R.A.; Azevedo, R.A. Exogenous Application of L-Arginine Improves Protein Content and Increases Yield of Pereskia aculeata Mill. Grown in Soilless Media Container. Horticulturae 2022, 8, 142. https:/ / doi.org/10.3390/horticulturae8020142

Academic Editors: Andrea Ertani and Michela Schiavon

Received: 8 November 2021 Accepted: 10 December 2021 Published: 7 February 2022

Publisher's Note: MDPI stays neutral with regard to jurisdictional claims in published maps and institutional affiliations.

Copyright: (c) 2022 by the authors. Licensee MDPI, Basel, Switzerland. This article is an open access article distributed under the terms and conditions of the Creative Commons Attribution (CC BY) license (https:// creativecommons.org/licenses/by/ $4.0 /)$.
1 Department of Crop Production, "Luiz de Queiroz" College of Agriculture, University of São Paulo, Piracicaba 13418-900, Brazil; vy141@hotmail.com (V.J.C.); scmello@usp.br (S.C.M.); ddourado@usp.br (D.D.N.)

2 Department of Biological Sciences, "Luiz de Queiroz" College of Agriculture, University of São Paulo, Piracicaba 13418-900, Brazil; brunaisadorat@usp.br (B.I.T.); tmsacioly@hotmail.com (T.M.S.A.); rakluge@usp.br (R.A.K.)

3 Department of Genetics, "Luiz de Queiroz" College of Agriculture, University of São Paulo, Piracicaba 13418-900, Brazil; raa@usp.br

* Correspondence: isabela.scavacini.freitas@usp.br

Abstract: The Brazilian flora is one of the richest in biodiversity and has many species with high pharmaceutical and nutraceutical potential. Among these species is ora-pro-nobis (Pereskia aculeata Mill.), which stands out for the high protein content found in its leaves. The exogenous application of amino acids in crop production has shown promising results, such as the increase in productivity and plant quality, besides their capacity in alleviating environmental stress in plants. Exogenous application of L-arginine $\left(0,0.25,1.0\right.$ and $2.0 \mathrm{~g} \mathrm{~L}^{-1}$ of water) was performed by drenching on coconut fiber growing media of ora-pro-nobis plants. Plant growth parameters analyzed were chlorophylls and carotenoids contents, crude protein content, and determination of enzymes and oxidative stress substances. The higher concentration of L-arginine $\left(2 \mathrm{~g} \mathrm{~L}^{-1}\right.$ of water) increased net photosynthetic rate, leaf area, plant fresh and dry mass, carotenoids content and crude protein content in leaves. Thus, the exogenous application of L-arginine in ora-pro-nobis plants can improve both the productivity and nutritional value of its leaves.

Keywords: amino acids; oxidative stress; protein content; unconventional food plants

\section{Introduction}

Brazil has one of the richest flora biodiversity of the world. Many plant species with great commercial potential and high nutritional value are still underexploited. Within the group of the Unconventional Food Plants (UFP) is ora-pro-nobis, which is a native plant of the Brazilian flora and belongs to the Cactaceae family [1,2].

Ora-pro-nobis leaves are consumed as fresh salad, sautéed, or used as flour. The flour made from the leaves is higher in protein (about $25 \mathrm{~g}$ of protein $100 \mathrm{~g}^{-1}$ ) than other foods such as boiled egg $\left(13 \mathrm{~g}\right.$ protein $\left.100 \mathrm{~g}^{-1}\right)$, beef $\left(22 \mathrm{~g}\right.$ protein $\left.100 \mathrm{~g}^{-1}\right)$, oats $(13.9 \mathrm{~g}$ of protein $100 \mathrm{~g}^{-1}$ ) and carioca beans ( $4.8 \mathrm{~g}$ of protein $100 \mathrm{~g}^{-1}$ ) [3]. Thus, this crop is an important source of protein and indicated to the diet of protein-deficient populations. Protein deficiency results in the emergence of diseases such as malnutrition, which is the main health problem in developing countries [4]. Ora-pro-nobis is also a source of fiber and

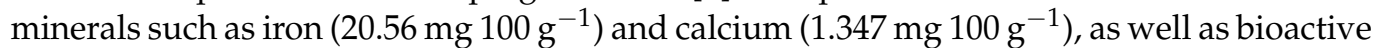

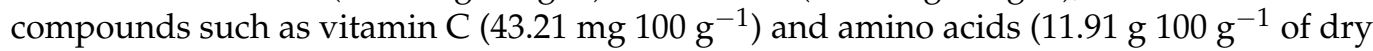
leaves), among which are leucine, lysine, phenylalanine, valine and arginine $[2,5]$. 
This species has great exploratory potential due to its high nutritional quality, easy vegetative propagation capacity, and rusticity [6]. However, adult plants have shoots with sharp spine-bearing areoles [7], complicating leaf harvesting. Therefore, cultivation systems that allow high yield and quality in younger plants is a new promisor alternative to growers. Thus, the development of soilless ora-pro-nobis cultivation in greenhouses with nutrition management may improve the nutritional quality and productivity.

The nutrition management includes the nitrogen that is among the most important elements to improve the yield and protein content as an integral component of proteins. This element is absorbed in the form of nitrate $\left(\mathrm{NO}_{3}{ }^{-}\right)$and ammonium $\left(\mathrm{NH}_{4}\right)$ or $\mathrm{N}_{2}$ from the atmosphere through nitrogen-fixing bacteria. In addition, substances as amino acids act as regulators of nitrogen uptake and bioestimulants to alleviate abiotic stresses, improving plant quality and commercial yield.

Among amino acids, arginine is a precursor to mediators of biological and physiological processes such as nitric oxide (NO), proline and polyamines, which are important compounds for abiotic stress signaling and response [8-10]. Moreover, it is important for protein synthesis, because it has the lowest $C: N$ ratio among the 21 proteinogenic amino acids and is therefore the largest form of organic nitrogen storage and transport in plants [11]. Polyamines may be important for the induction of cell division [12], since the application of arginine increases the level of endogenous cytokinines, increasing the number of leaves, leaf area, number of tillers and, consequently, productivity, as observed in wheat plants [13]. Arginine can also play an important role in root development and growth [14].

Besides the endogenous arginine synthesis, plants are also able to absorb amino acids from exogenous applications, which can contribute to different physiological and biochemical processes, such as protein synthesis. Amino acids such as L-arginine (L-Arg) in liquid form are applied on leaves as well as directly to soil or substrate (by drenching). When sprayed on leaves, the solution must overcome two barriers to be absorbed: the cuticle to enter the apoplast and the plasma membrane to pass from the apoplast to the symplast. Thus, foliar absorption depends on the thickness and composition of the cuticle, among other factors. The leaf limb of ora-pro-nobis has epidermal cells with polygonal anticlinal walls, and relatively thick and striated cuticle, which coats the uni-stratified epidermis [15]. Thus, foliar absorption of amino acids is reduced in this plant species. However, roots can also absorb amino acids present in soil solution. This absorption pathway is mediated by root transporters, such as AAP5, responsible for lysine and arginine input [16].

Successful exogenous amino acid application has been reported to several crops, such as maize [17,18], beans [19], sugar cane [20], soybean [21], oregano [22] and lettuce [23,24]. The exogenous L-arginine application is also beneficial for the growth and development of plants under stress conditions [25]. Therefore, the aim of this research was to evaluate the efficiency of L-arginine application by drenching on ora-pro-nobis grown under soilless system in greenhouse, with the hypothesis that this amino acid could increase yield and nutritional quality of this species due to the role of arginine in plants.

\section{Materials and Methods}

\subsection{Experimental Site}

The experiment was carried out between April and June 2018 in a greenhouse located at the experimental site of Crop Science Department of "Luiz de Queiroz" College of Agriculture, University of São Paulo, Piracicaba (SP), Brazil (22 $42^{\prime} 27^{\prime \prime}$ S, $47^{\circ} 37^{\prime} 41^{\prime \prime} \mathrm{W}$, $546 \mathrm{~m}$ of altitude). According to Köppen climate classification, this region is a Cwa type (altitude tropical climate), with temperatures above $22^{\circ} \mathrm{C}$ in summer, dry winter (June, July and August) and rainfall concentrated in summer (December, January and February). The greenhouse roof was covered by polyethylene film of $150 \mu \mathrm{m}$ and anti-aphid screens to protect its sides. 


\subsection{Seedling Production and Transplant}

Ora-pro-nobis seedlings were produced by vegetative propagation of cuttings from an adult mother plant located at the Medicinal Plants Garden of "Luiz de Queiroz" College of Agriculture, University of São Paulo. Herbaceous cuttings with $20 \mathrm{~cm}$ long and 0.8 to $1.0 \mathrm{~cm}$ diameter were taken from the middle part of mature and non-lignified branches, and planted in trays ( 72 cells of $4 \mathrm{~cm} \cdot 4 \mathrm{~cm} \cdot 4 \mathrm{~cm}$ each) filled with substrate composed by pine bark, peat, charcoal and vermiculite substrate, fertilized with $14 \% \mathrm{~N}, 7 \% \mathrm{P}, 14.9 \% \mathrm{~K}$ (14-16-18) and micronutrients, with water retention capacity of $150 \%$, electrical conductivity (EC) of $0.7 \mathrm{dS} \mathrm{m}^{-1} \pm 0.3$ and $\mathrm{pH} 5.8 \pm 0.5$. The trays were maintained in a greenhouse and the cuttings were irrigated to keep the water level at recipient capacity. The rooted cuttings were transplanted after 20 days into $4 \mathrm{~L}$ plastic pots $(18.5 \mathrm{~cm}$ height, $22 \mathrm{~cm}$ upper diameter and $16 \mathrm{~cm}$ lower diameter) filled with coconut fiber-based substrate. The pots were placed in double rows array, spacing $0.40 \mathrm{~m}$ between plants and $0.40 \mathrm{~m}$ between rows and $1.60 \mathrm{~m}$ between double rows in the greenhouse.

\subsection{Irrigation and Nutrition}

Plant nutrition and irrigation occurred by drip fertigation system, which consisted of two $0.5 \mathrm{hp}$ motor pumps, disc filters, two $500 \mathrm{~L}$ boxes and $8 \mathrm{~L} \mathrm{~h}^{-1}$ self-compensating drippers inserted into $16 \mathrm{~mm}$ polyethylene tubes. Each drip nozzle had a four-output splitter, each one connected to a $0.7 \mathrm{~m}$ long microtube. Each pot had two drippers with flow rates of $2 \mathrm{~L} \mathrm{~h}^{-1}$. Irrigation system uniformity tests were performed both at the time of system installation (before transplanting) and throughout the cultivation cycle to ensure a uniform distribution of the nutrient solution in all treatments. The plants were irrigated daily to maintain the substrate humidity content at water tension of $3 \mathrm{kPa}$. The irrigation system was monitored by sensors (Irrigas ${ }^{\circledR}$ ), which automatically triggered the irrigation system when the substrate reached the tension of $4 \mathrm{kPa}$.

The nutrient solution applied to the plants was composed of $183.5 \mathrm{ppm} \mathrm{N}, 42.80 \mathrm{ppm}$ P, 200.20 ppm K, 150.00 ppm Ca, 40.10 ppm Mg, 76.60 ppm S, 1.18 ppm B, 0.73 ppm Cu, $4.82 \mathrm{ppm} \mathrm{Fe}, 0.73$ ppm Mn, $0.14 \mathrm{ppm}$ Mo $0.29 \mathrm{ppm} \mathrm{Zn}$ and $0.13 \mathrm{ppm}$ Ni. The EC of the nutrient solution was $2.3 \mathrm{dS} \mathrm{m}^{-1}$ and $\mathrm{pH}$ 5.7. EC and $\mathrm{pH}$ meters were used to evaluate and record these parameters of the nutrient solution in the media container.

\subsection{Experimental Design and Treatments}

The experiment was carried out in randomized block design with four treatments composed by three rates of L-arginine $\left(0.25,1.00\right.$ and $2.00 \mathrm{~g}$ of L-arginine $\mathrm{L}^{-1}$ of deionized water) and control, with four replications. Each replication had four plants, with a total of 64 plants in the experiment. The L-arginine was applied at noon time by drench at 45 , 52,59 and 71 days after transplant (DAT) of the rooted cuttings. The volume of solution with L-arginine was calculated to replace the nutrient solution that would be applied to maintain the substrate humidity level in the container at tension of $3 \mathrm{kPa}$. On average, it was applied 30 to $40 \mathrm{~mL}$ of each L-arginine concentration per pot.

\subsection{Sample Collection and Storage for Biochemical Analysis}

Five leaves located in the middle part of mature branches were collected per plot at 72 DAT to analyze the antioxidant enzymes activity, oxidative stress indicating substances quantity, chlorophylls and carotenoids content. The samples were collected in the morning and were immediately wrapped in foil, frozen in liquid nitrogen and conserved at $-80^{\circ} \mathrm{C}$.

\subsection{Assessment of Antioxidant Enzymes Activity}

The frozen samples were mixed with liquid nitrogen and macerated in porcelain crucibles using a pistil. A total of $1 \mathrm{~g}$ of each sample was mixed to $0.2 \mathrm{~g}$ of polyvinylpolypyrrolidone (PVPP) and to $3 \mathrm{~mL}$ of $100 \mathrm{mM}$ extraction buffer ( $\mathrm{pH} 7.5)$ for protein extraction. These samples were centrifuged at $10,000 \mathrm{rpm}$ for $30 \mathrm{~min}$ at $4{ }^{\circ} \mathrm{C}$ for separation of solid and liquid phases. The supernatant (extract solution) was packed in $2 \mathrm{~mL}$ tubes for subsequent 
quantification of catalase (CAT), superoxide dismutase (SOD) and ascorbate peroxidase (APX) enzymes.

CAT was determined according to the methodology proposed by Kraus et al. [26] and modified by Azevedo et al. [27]. The sample was prepared by adding $25 \mu \mathrm{L}$ of the extract solution to the reaction solution composed of $1 \mathrm{~mL}$ of $100 \mathrm{mM}$ potassium phosphate buffer ( $\mathrm{pH} 7.5$ ) and $2.5 \mu \mathrm{L}$ of hydrogen peroxide (final concentration of $24.5 \mu \mathrm{M}$ ). CAT activity was determined spectrophotometrically at an absorbance of $240 \mathrm{~nm}$ by the decomposition of the $\mathrm{H}_{2} \mathrm{O}_{2}$ present in the sample and was expressed in $\mu \mathrm{mol} \mathrm{mg^{-1 }}$ of protein $\mathrm{min}^{-1}$.

SOD activity was assayed using the methodology proposed by Giannopolitis and Ries [28]. Then, $15 \mu \mathrm{L}$ of the extract solution was added to a test tube with solution composed of $9.5 \mu \mathrm{L}$ riboflavin $(0.1 \mathrm{mM}), 390 \mu \mathrm{L}$ methionine $(50 \mathrm{mM}), 9.5 \mu \mathrm{L}$ NBT $(1 \mathrm{mM})$, $15 \mu \mathrm{L}$ EDTA $(10 \mathrm{mM})$ and $966 \mu \mathrm{L}$ phosphate buffer $(50 \mathrm{mM}-\mathrm{pH}$ 7.8). The mixture was stirred for $30 \mathrm{~s}$ and the reaction was performed at $25^{\circ} \mathrm{C}$ in a chamber (covered in aluminum foil) with a fluorescent light of $15 \mathrm{~W}$, and after $5 \mathrm{~min}$ of light exposure, the light source was turned off and the blue formazane compound produced by NBT photoreduction was measured in spectrophotometer (Genesys 10 S UV-VIS) at $560 \mathrm{~nm}$. The same assay was done without protein extract, which was kept in the dark and used as negative control. The quantification was expressed in $\mathrm{U} \mathrm{mg}^{-1}$ of protein. One unit (U) of SOD corresponds to the amount of SOD that inhibits the photochemical reduction of NBT by $50 \%$.

APX activity was determined according to Nakano and Asada [29]. The reaction solution consisted of $650 \mu \mathrm{L}$ of $80 \mathrm{mM}$ potassium phosphate buffer ( $\mathrm{pH} 7.0), 100 \mu \mathrm{L}$ of ascorbic acid $(5 \mathrm{mM})$ and $100 \mu \mathrm{L}$ EDTA $(1 \mathrm{mM})$. The solution was stowed in a light-protected container and placed in water bath at $30^{\circ} \mathrm{C}$. The reaction was started by mixing $50 \mu \mathrm{L}$ of the extract solution and $100 \mu \mathrm{L}$ of hydrogen peroxide $(1 \mathrm{mM})$ to $850 \mu \mathrm{L}$ of the reaction solution. APX activity was determined by monitoring the rate of ascorbate oxidation. The reading was performed for $1 \mathrm{~min}$ in a spectrophotometer at $290 \mathrm{~nm}$ and the enzymatic activity determined using the molar extinction coefficient of $2.8 \mathrm{mM}^{-1} \mathrm{~cm}^{-1}$. The quantification was expressed in nmol min ${ }^{-1} \mathrm{mg}^{-1}$ of protein.

\subsection{Assessment of Oxidative Stress Indicating Substances}

The hydrogen peroxide $\left(\mathrm{H}_{2} \mathrm{O}_{2}\right)$ quantification was performed according to Alexieva et al. [30]. The samples were macerated with TCA (0.1\%) in a proportion of 1:100 (weight/volume). After homogenization, the samples were transferred to tubes and centrifuged at $10,000 \mathrm{rpm}$ for $10 \mathrm{~min}$ at $4{ }^{\circ} \mathrm{C}$. A volume of $200 \mu \mathrm{L}$ of supernatant was removed, and $800 \mu \mathrm{L}$ of potassium iodide $(1 \mathrm{M})$ and $200 \mu \mathrm{L}$ of $100 \mathrm{mM}$ potassium phosphate buffer ( $\mathrm{pH}$ 7.5) were added. Then, the solutions in the tubes were stored at room temperature for one hour at absence of light. After this period, the samples were maintained at room temperature for $15 \mathrm{~min}$ and protected from light for spectrophotometrically reading at $390 \mathrm{~nm}$ wavelength. The amount of $\mathrm{H}_{2} \mathrm{O}_{2}$ in the sample was expressed in $\mu$ molar $\mathrm{g}^{-1}$ of fresh weight.

The quantification of malonaldehyde (MDA) was performed according to Heath and Packer [31]. The samples were macerated with 2-thiobarbituric acid (TBA) $(0.1 \%)$ in a proportion of 1:100 (weight/volume) along with 20\% PVPP. After homogenization, the macerated samples were centrifuged at 10,000 rpm for $10 \mathrm{~min}$ at $4{ }^{\circ} \mathrm{C}$. A volume of $250 \mu \mathrm{L}$ of the supernatant was removed and placed in $2 \mathrm{~mL}$ tube with $1 \mathrm{~mL}$ of a solution composed of TCA $(20 \%)$ and TBA $(0.5 \%)$. The mixture was placed in water bath for $30 \mathrm{~min}$ at $95^{\circ} \mathrm{C}$. Then, the samples were cooled and centrifuged for $10 \mathrm{~min}$ at 10,000 rpm. The absorbance readings were taken at $535 \mathrm{~nm}$ and $600 \mathrm{~nm}$ using a spectrophotometer. The content of MDA was expressed in $\mathrm{nmol} \mathrm{g}^{-1}$ of fresh weight.

\subsection{Chlorophyll and Carotenoid Analysis}

Chlorophyll and carotenoid assessments were performed according to Lichtenthaler and Wellburn [32]. A total of $10 \mathrm{~mL}$ of $100 \%$ acetone were added to $10 \mathrm{mg}$ of lyophilized leaves of each sample. After stirring, the samples were left out of light and at room 
temperature for extraction. After $1 \mathrm{~h}$ and $30 \mathrm{~min}$, the extract was filtered on filter paper and read by a spectrophotometer (BIOCHROM, Libra S22) at wavelengths of $661 \mathrm{~nm}$ and $644 \mathrm{~nm}$ to determine chlorophyll a (Chl $a, \mathrm{mg} \mathrm{g}^{-1}$ lyophilized leaves) and b (Chl b, $\mathrm{mg} \mathrm{g}^{-1}$ lyophilized leaves), and $465 \mathrm{~nm}$ for determination of total carotenoids (Carot, $\mathrm{mg} \mathrm{g}^{-1}$ lyophilized leaves). Total amount of chlorophyll (Total Chl, $\mathrm{mg} \mathrm{g}^{-1}$ lyophilized leaves) was calculated by the sum of chlorophylls a and $b$.

\subsection{Crude Protein Content in Leaves}

Samples were dried in a convective-air oven at $65^{\circ} \mathrm{C}$ until constant mass and grounded using a Wiley mill (Marconi, Piracicaba, Sao Paulo, Brazil) to pass a $1 \mathrm{~mm}$ screen. Crude protein content $(C P)$ analysis was based on the determination of nitrogen in dried leaves according to the methodology no.991.20 of the AOAC [33], which is done in three steps: Kjeldahl digestion, distillation and titration. Approximately $1 \mathrm{~g}$ of the sample was added to Kjeldahl digestion flask with sulfuric acid and a catalyst, forming ammoniacal sulfate. In the second step, the ammonia was distilled and added to an Erlenmeyer flask containing $4 \%$ boric acid and a screen methyl red indicator, turning the solution into a green color. The solution was titrated with $0.1 \mathrm{~N}$ sulfuric acid until it becomes light pink. Protein determination was calculated using the formula: CP $(\%)=V \cdot \mathrm{cf} \cdot 0.0014 \cdot 100 \cdot \mathrm{CF} / W$, where $V$ is the volume of sulfuric acid used in the titration, cf is the sulfuric acid correction factor, CF is the nitrogen to protein conversion factor (6.25 for vegetable proteins) and $W$ is the sample dry weight.

\subsection{Physiological Parameters}

Photosynthetic parameters were evaluated at 72 DAT by a portable infrared gas meter (IRGA, LI 6400XT, LI-COR; Lincoln, NE, USA). The measurements were made on a sunny day, between 8:00 and 11:00 h, in fully expanded mature leaves, from the mid-branch of one plant per plot. The photosynthetic parameters evaluated were net assimilation rate $(A$, $\left.\mu \mathrm{mol} \mathrm{CO} 2 \mathrm{~m}^{-2} \mathrm{~s}^{-1}\right)$, stomatal conductance $\left(G s \mathrm{~mol} \mathrm{~m}^{-2} \mathrm{~s}^{-1}\right)$, transpiration rate $(E, \mathrm{mmol}$ $\left.\mathrm{H}_{2} \mathrm{O} \mathrm{m}^{-2} \mathrm{~s}^{-1}\right)$ internal $\mathrm{CO}_{2}$ leaf concentration $\left(\mathrm{Ci}, \mu \mathrm{mol} \mathrm{CO} \mathrm{Col}^{-1}\right.$ air$)$.

\subsection{Growth Parameters}

The number of shoots and leaves were counted, and the total stem length was measured at different plant developmental stages (14, 28, 43, 57 and 69 DAT). At the end of the experiment (71 DAT), two whole plants were collected per plot to perform the following growth analyzes: fresh and dry mass $(\mathrm{g})$ of stems, leaves and roots. For this, each tissue of plant was weighed and dried in a convective air oven at $65^{\circ} \mathrm{C}$ until constant mass. Total plant dry mass was calculated by the sum of the dry mass of roots, stems and leaves. The shoot to root ratio was calculated from the shoot dry mass $(\mathrm{g})$ and root dry mass. The water content in the roots, stems and leaves was also calculated. Leaf area $\left(\mathrm{cm}^{2}\right)$ of plant was determined by an area meter (LI-3100C, LI-COR; Lincoln, NE, USA).

\subsection{Statistical Analysis}

Homogeneity and variance analyses were made by the Shapiro-Wilk and the F tests, respectively. The means were compared by LSD test $(p<0.05)$ using SAS/STAT ${ }^{\circledR}$ program (SAS Institute, Cary, NC, USA).

\section{Results}

\subsection{Antioxidant Enzymes and Oxidative Stress Indicating Substances}

SOD enzyme activity was reduced due to L-arginine exogenous application (Figure 1A). The highest reduction percentage $(25.5 \%)$ was obtained by the highest rate of this amino acid $\left(2 \mathrm{~g} \mathrm{~L}^{-1}\right)$. The activity of CAT enzyme increased by $75.7 \%, 43.7 \%$ and $42.7 \%$ with the application of $2 \mathrm{~g} \mathrm{~L}^{-1}$ in relation to the control and treatments equivalent to 0.25 and $1.0 \mathrm{~g} \mathrm{~L}^{-1}$, respectively (Figure $1 \mathrm{C}$ ). APX enzyme activity and $\mathrm{H}_{2} \mathrm{O}_{2}$ and MDA content were not significantly affected by the application of L-arginine (Figure 1B,D,E). 

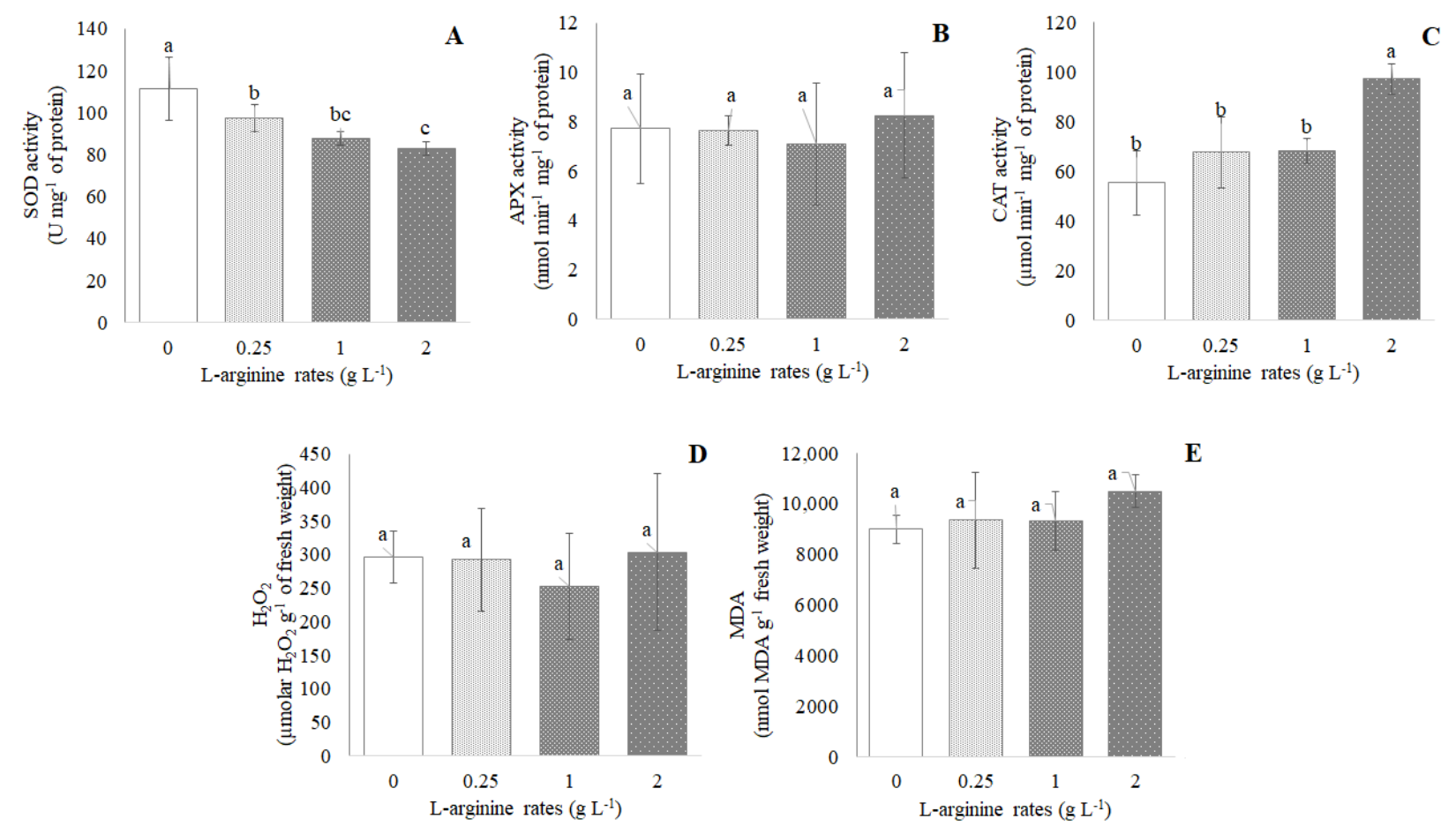

Figure 1. (A) Superoxide dismutase activity ( $\mathrm{U} \mathrm{mg}^{-1}$ of protein); (B) ascorbate peroxidase activity

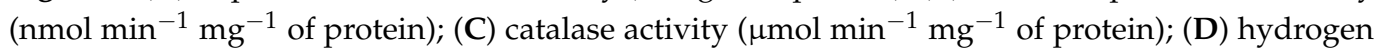
peroxide content ( $\mu$ molar $\mathrm{H}_{2} \mathrm{O}_{2} \mathrm{~g}^{-1}$ of fresh weight); and (E) lipidic peroxidation (nmol MDA g ${ }^{-1}$ of fresh weight) from ora-pro-nobis leaves in function of different rates of L-arginine exogenous application. Data followed by the same letter did not differ from each other by Tukey range test at $p \leq 0.05$.

\subsection{Crude Protein Content}

The exogenous application of L-arginine significantly increased the $C P$ content in ora-pro-nobis leaves. The highest rate of L-arginine $\left(2 \mathrm{~g} \mathrm{~L}^{-1}\right)$ was responsible to improve the $C P$ content in $15 \%$ (Figure 2 ).

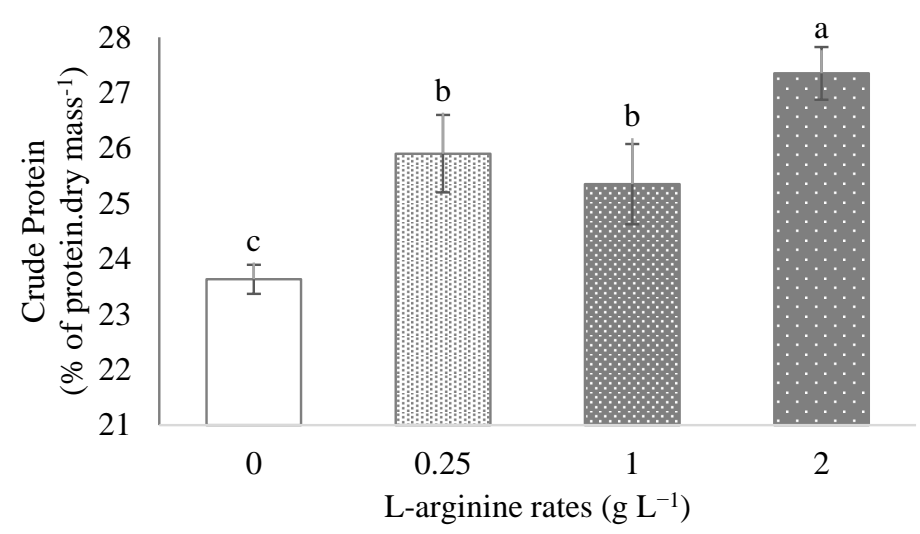

Figure 2. Crude protein in ora-pro-nobis leaves in function of different rates of exogenous L-arginine application. Data followed by the same letter did not differ from each other by Tukey range test at $p \leq 0.05$.

\subsection{Photosynthesis and Pigments}

The exogenous application of L-arginine increased the net assimilation rate $(A)$ and decreased internal $\mathrm{CO}_{2}$ leaf concentration ( $\mathrm{C} i$ ) (Table 1). No statistical differences were observed between treatments for other photosynthetic parameters. The treatment with the highest rate of L-arginine significantly increased the content of chlorophyll a (Chl a) and 
carotenoids (Carot) in relation to control (Table 2). Chl a was the most abundant pigment and it was on average about 3 times higher than the Chl b content. The ratio of Total Chl/Carot was on average 1.97 .

Table 1. Net assimilation rate $\left(A, \mu \mathrm{mol} \mathrm{CO} \mathrm{Cm}^{-2} \mathrm{~s}^{-1}\right)$, stomatal conductance $\left(G s, \mathrm{~mol} \mathrm{~m}^{-2} \mathrm{~s}^{-1}\right)$, internal $\mathrm{CO}_{2}$ leaf concentration $\left(\mathrm{Ci}, \mu \mathrm{mol} \mathrm{CO} \mathrm{Col}^{-1}\right.$ air) and transpiration rate $\left(E, \mathrm{mmol} \mathrm{H}_{2} \mathrm{O} \mathrm{m}^{-2} \mathrm{~s}^{-1}\right)$, in ora-pro-nobis leaves treated with different L-arginine rates applied by drenching.

\begin{tabular}{ccccc}
\hline Rates $\left(\mathbf{g ~ L}^{-\mathbf{1}}\right)$ & $\boldsymbol{A}$ & $\boldsymbol{G} \boldsymbol{C}$ & $\boldsymbol{C}$ & $\boldsymbol{E}$ \\
\hline 0 & $9.33 \pm 1.16 \mathrm{~b}$ & $0.099 \pm 0.003 \mathrm{a}$ & $230.66 \pm 13.53 \mathrm{a}$ & $1.27 \pm 0.13 \mathrm{a}$ \\
0.25 & $11.18 \pm 1.29 \mathrm{ab}$ & $0.119 \pm 0.024 \mathrm{a}$ & $212.64 \pm 16.43 \mathrm{ab}$ & $1.34 \pm 0.30 \mathrm{a}$ \\
1 & $10.85 \pm 1.34 \mathrm{ab}$ & $0.083 \pm 0.024 \mathrm{a}$ & $191.76 \pm 19.45 \mathrm{~b} \mathrm{c}$ & $1.16 \pm 0.21 \mathrm{a}$ \\
2 & $12.84 \pm 1.51 \mathrm{a}$ & $0.101 \pm 0.007 \mathrm{a}$ & $172.29 \pm 12.20 \mathrm{c}$ & $1.24 \pm 0.05 \mathrm{a}$ \\
LSD & 2.73 & 0.039 & 30.02 & 0.43 \\
CV $(\%)$ & 5.35 & 9.76 & 7.44 & 8.46 \\
\hline
\end{tabular}

Notes: LSD least significant difference; CV coefficient of variation; means followed by the same letter in the column did not differ from each other by Tukey range test at $p \leq 0.05$.

Table 2. Chlorophyll a (Chl a), chlorophyll b (Chl b), total chlorophyll (Total Chl) and carotenoids (Carot) contents in $\mathrm{mg} \mathrm{g}^{-1}$ of lyophilized leaves from ora-pro-nobis plants treated with different L-arginine rates applied by drenching.

\begin{tabular}{ccccc}
\hline Rates $\left(\mathbf{g ~ L}^{-1}\right)$ & Chl $\boldsymbol{a}$ & Chl $\boldsymbol{b}$ & Total Chl & Carot \\
\hline 0 & $7.82 \pm 0.56 \mathrm{~b}$ & $2.25 \pm 0.34 \mathrm{a}$ & $10.19 \pm 0.81 \mathrm{a}$ & $4.92 \pm 0.59 \mathrm{~b}$ \\
0.25 & $8.11 \pm 0.10 \mathrm{ab}$ & $2.47 \pm 0.09 \mathrm{a}$ & $10.59 \pm 0.17 \mathrm{a}$ & $5.33 \pm 0.08 \mathrm{ab}$ \\
1 & $7.76 \pm 0.37 \mathrm{~b}$ & $2.36 \pm 0.19 \mathrm{a}$ & $10.12 \pm 0.56 \mathrm{a}$ & $5.08 \pm 0.20 \mathrm{~b}$ \\
2 & $8.57 \pm 0.18 \mathrm{a}$ & $2.45 \pm 0.12 \mathrm{a}$ & $11.06 \pm 0.26 \mathrm{a}$ & $5.66 \pm 0.12 \mathrm{a}$ \\
LSD & 0.63 & 0.36 & 0.94 & 0.54 \\
CV (\%) & 4.92 & 9.34 & 5.62 & 6.46 \\
\hline
\end{tabular}

Notes: LSD least significant difference; CV coefficient of variation; means followed by the same letter in the column did not differ from each other by Tukey range test at $p \leq 0.05$.

\subsection{Plant Growth and Yield}

The application of $2 \mathrm{~g} \mathrm{~L}^{-1}$ of L-arginine promoted an increase of $26.8 \%$ in the leaf area of ora-pro-nobis plants compared to the control (Figure 3). Increases of $19.65 \%, 28.67 \%$ and $31.74 \%$ were obtained to leaf fresh mass, leaf dry mass and total dry mass, respectively, due to the application of the highest rate of L-arginine (Table 3). The number of shoots as well as the total stem length and the number of leaves were not influenced by exogenous application of L-arginine at different plant developmental stages (14, 28, 43, 57, 69 DAT). The averages of these parameters were $5.0,27 \mathrm{~cm}$ and 15.8 at 43 DAT, $5.1,42.2 \mathrm{~cm}$ and 22.5 at 57 DAT, and $5.1,65.4 \mathrm{~cm}$ and 32.2 at 69 DAT for number of shoots, total stem length and number of leaves, respectively.

Table 3. Fresh mass (g), dry mass (g) and water content (\%) of ora-pro-nobis plants treated with different L-arginine rates applied by drenching.

\begin{tabular}{|c|c|c|c|c|c|c|c|c|}
\hline \multirow{2}{*}{$\begin{array}{l}\text { Rates } \\
\left(\mathrm{g} \mathrm{L}^{-1}\right)\end{array}$} & \multicolumn{3}{|c|}{ Fresh Mass } & \multicolumn{3}{|c|}{ Dry Mass } & \multicolumn{2}{|c|}{ Water Content } \\
\hline & Leaves & Stems & Total & Leaves & Stems & Total & Leaves & Total \\
\hline 0 & $132.5 \pm 21.9^{b}$ & $68.7 \pm 17.0^{\mathrm{a}}$ & $224.9 \pm 53.2^{a}$ & $12.7 \pm 2.1^{b}$ & $12.5 \pm 3.4^{a}$ & $28.2 \pm 5.8^{b}$ & $90.5 \pm 0.2^{a}$ & $87.4 \pm 1.0^{\mathrm{a}}$ \\
\hline 0.25 & $146.5 \pm 11.9^{\mathrm{ab}}$ & $94.8 \pm 14.8^{\mathrm{a}}$ & $264.5 \pm 39.2^{\mathrm{a}}$ & $14.6 \pm 1.1^{\mathrm{ab}}$ & $17.4 \pm 2.8^{\mathrm{a}}$ & $36.0 \pm 5.1^{\mathrm{ab}}$ & $90.1 \pm 0.1^{\mathrm{ab}}$ & $86.7 \pm 0.6^{b}$ \\
\hline 1 & $155.2 \pm 11.4^{\mathrm{ab}}$ & $82.5 \pm 10.6^{a}$ & $254.4 \pm 34.1^{\mathrm{a}}$ & $15.6 \pm 1.5^{\mathrm{a}}$ & $15.5 \pm 2.8^{\mathrm{a}}$ & $34.7 \pm 5.1^{\mathrm{ab}}$ & $90.0 \pm 0.3 b^{c}$ & $86.9 \pm 0.3^{\mathrm{ab}}$ \\
\hline 2 & $158.5 \pm 9.6^{\mathrm{a}}$ & $95.4 \pm 20.8^{a}$ & $275.4 \pm 21.7^{\mathrm{a}}$ & $16.4 \pm 1.0^{\mathrm{a}}$ & $17.1 \pm 3.3^{\mathrm{a}}$ & $37.1 \pm 3.6^{\mathrm{a}}$ & $89.6 \pm 0.4^{c}$ & $86.6 \pm 1.2^{b}$ \\
\hline LSD & 23.86 & 27.23 & 63.69 & 2.43 & 5.21 & 8.74 & 0.43 & 0.47 \\
\hline CV (\%) & 10.07 & 19.94 & 15.63 & 10.25 & 20.87 & 16.07 & 0.3 & 0.34 \\
\hline
\end{tabular}

Notes: LSD least significant difference; CV coefficient of variation; means followed by the same letter in the column did not differ from each other by Tukey range test at $p \leq 0.05$. 


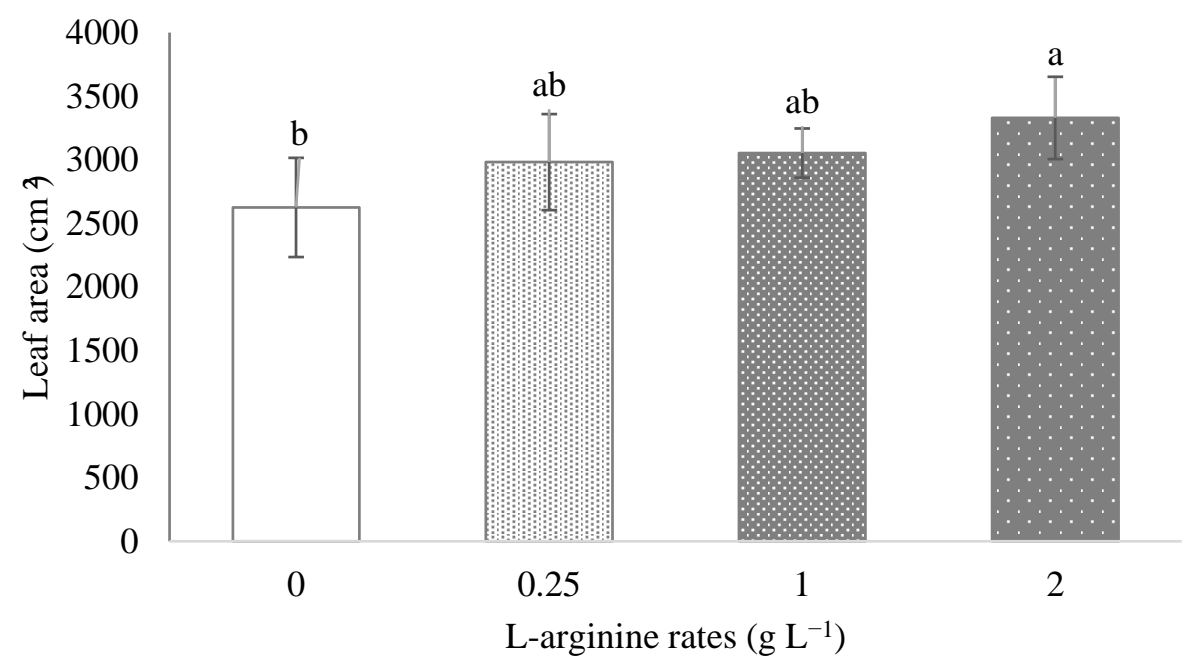

Figure 3. Leaf area of ora-pro-nobis plants treated with different L-arginine rates applied by drenching. Data followed by the same letter did not differ from each other by Tukey range test at $p \leq 0.05$.

\section{Discussion}

To control the level of ROS, plants have an antioxidant defense system composed of enzymes such as SOD, CAT, APX and other substances (ascorbic acid, carotenoids, phenolic acids, nonprotein amino acids, among others), which are responsible for eliminating excess accumulated ROS in plants under stress [34]. Arginine is known to be a precursor to important mediators of biological and physiological processes related to abiotic stress signaling and response. Therefore, this amino acid can interfere in the antioxidant response when applied during plant growth [35]. However, exogenous application of L-arginine has generated different results, considering different species, plant development stages, cropping systems and climatic conditions.

In our study, the application of L-arginine did not affect APX enzyme activity and, consequently, MDA levels. Although the influence of L-arginine on $\mathrm{H}_{2} \mathrm{O}_{2}$ and MDA production was not observed in ora-pro-nobis, Nasibi et al. [36] obtained a reduction in the amount of these oxidative stress indicating substances after the application of L-arginine on tomatoes grown under water stress. However, in accordance with our study, these same authors did not observe statistical differences in APX activity in tomatoes under stress-free environment.

L-arginine regulated the SOD and CAT enzyme activity. This amino acid is a precursor for biosynthesis of nitric oxide (NO), polyamines and other compounds [37] and its exogenous application increases the NO content in plants [38]. NO regulates the antioxidant enzyme synthesis at the level of activity and gene expression [39]. Although there is no explanation to reduced SOD activity with exogenous L-arginine, the same effect in this enzyme activity was observed in Vicia faba after the application of an argininecontaining amino acid mixture [40]. Increased CAT activity with $2 \mathrm{~g} \mathrm{~L}^{-1}$ of L-arginine was not effective to reduce $\mathrm{H}_{2} \mathrm{O}_{2}$ level in plants of ora-pro-nobis. However, enhanced growth and development parameters may have been positively influenced by increased CAT activity [41-44].

The increased photosynthetic rate by L-arginine application at rate of $2 \mathrm{~g} \mathrm{~L}^{-1}$ via root system (Table 1 ) is associated with the functions of L-arginine in the physiological process in plants [45]. Arginine is an important nitrogen storage form, and this element is a major component of the photosynthetic apparatus. Thus, arginine metabolism plays a key role in nitrogen distribution and recycling in plants [46]. In addition, arginine is a precursor of polyamines that can promote the photosynthesis [47].

The increased foliar area by L-arginine (Figure 3) may have led to more photoassimilate synthesis and thus, greater carbohydrate availability to enhance the fresh and dry weight 
of leaves and protein content. In addition to nitrogen input, arginine raises the level of endogenous cytokine, increasing leaf area, number of leaves and shoots [13].

According to El-Bassiouny et al. [13], polyamines also prevent chlorophyll degradation in higher plants. Therefore, the improvement in the content of chlorophyll a in ora-pronobis leaves in the highest rate of L-arginine $\left(2 \mathrm{~g} \mathrm{~L}^{-1}\right)$ treatment (Table 2) might be due to the greater synthesis of polyamines, as well as the higher nitrogen input, which is one of the key components of chlorophyll molecule [48]. An increase in pigment content, such as chlorophyll a and total carotenoids, was also observed by Ahmed et al. [49] in unstressed plants of Indian borage after exogenous application of L-arginine at $3 \mathrm{~g} \mathrm{~L}^{-1}$. Regarding to the nutritional value for this vegetable consumers, it is known that a dietary with high carotenoid intake is associated with health-related benefits such as a greater immune system and lower risk of degenerative chronic diseases development [50].

The highest rate of $\mathrm{L}$-arginine $\left(2 \mathrm{~g} \mathrm{~L}^{-1}\right)$ increased in $15.7 \%$ the $C P$ in leaves, reaching $27 \%$ of $C P$ in the leaf dry mass (Figure 2). This significant increase contributes to a better nutritional value of this vegetable. In addition, $85 \%$ of the $C P$ content found in ora-pronobis leaves is digestible and it also has adequate proportions of essential amino acids [51] for the human diet. This enhancement in protein content may be due to the presence of nitrogen in L-arginine composition, as in any other amino acid, directly affecting plant growth [52]. However, what differentiates arginine from others is that it has the lowest carbon to nitrogen ratio among the 21 proteinogenic amino acids [11], working as a building block for protein synthesis.

In conclusion, the response of photosynthetic rate, fresh and dry mass yield of leaves, leaf area, and the contents of chlorophyll a, carotenoids and crude protein is dependent of exogenous L-arginine rate. The treatment of L-arginine at concentration of $2 \mathrm{~g} \mathrm{~L}^{-1}$ was the best for improvement of protein content and yield of ora-pro-nobis. Therefore, this organic product retrieved from the anaerobic fermentation from the vegetable processing industry can be used as a biostimulant to raise ora-pro-nobis plants productivity and quality.

Author Contributions: Conceptualization, S.C.M., I.S.F., B.I.T. and T.M.S.A.; Methodology, S.C.M., I.S.F., B.I.T. and T.M.S.A.; Formal Analysis, I.S.F.; Investigation, I.S.F., B.I.T., T.M.S.A. and V.J.C.; Resources, R.A.K., R.A.A. and D.D.N.; Data Curation, I.S.F.; Writing-Original Draft Preparation, I.S.F.; Writing - Review and Editing, S.C.M. and I.S.F.; Project Administration, S.C.M. All authors have read and agreed to the published version of the manuscript.

Funding: This study was financed in part by the Coordenação de Aperfeiçoamento de Pessoal de Nível Superior-Brasil (CAPES)-Finance Code 001.

Acknowledgments: We thank Salete Aparecida Gaziola for helping us with the enzyme activity and oxidative stress indicating substances analysis.

Conflicts of Interest: The authors declare no conflict of interest.

\section{References}

1. Takeiti, C.Y.; Antonio, G.C.; Motta, E.M.P.; Collares-Queiroz, F.P.; Park, K.J. Nutritive Evaluation of a Non-Conventional Leafy Vegetable (Pereskia Aculeata Miller). Int. J. Food Sci. Nutr. 2009, 60, 148-160. [CrossRef]

2. De Almeida ME, F.; Junqueira AM, B.; Simão, A.A.; Corrêa, A.D. Caracterização Química Das Hortaliças Não-Convencionais Conhecidas Como Ora-pro-Nobis. Biosci. J. 2014, 30, 431-439.

3. NEPA/UNICAMP. Tabela Brasileira de Composição de Alimentos-TACO, 4th ed.; UNICAMP/NEPA Campinas: Campinas, Brazil, 2011.

4. Müller, O.; Krawinkel, M. Malnutrition and Health in Developing Countries. Can. Med Assoc. J. 2005, 173, 279-286. [CrossRef] [PubMed]

5. Trennepohl, B.I. Caracterização Físico-Química, Atividade Antioxidante e Atividades Biológicas da Espécie Pereskia Aculeata Mill; UFPR: Curitiba, Brazil, 2016.

6. Barbosa CK, R.; Finger, F.L.; Casali VW, D.; Oliveira LS, D.e.; Pereira, D.M. Manejo e Conservação Pós-Colheita de Pereskia Aculeata Mill. Em Temperatura Ambiente. Hortic. Bras. 2012, 30, S7002-S7009.

7. Butterworth, C.A.; Wallace, R.S. Molecular Phylogenetics of the Leafy Cactus Genus Pereskia (Cactaceae). Syst. Bot. 2005, 30, 800-808. [CrossRef]

8. Groppa, M.D.; Benavides, M.P. Polyamines and Abiotic Stress: Recent Advances. Amino Acids 2008, 34, 35. [CrossRef] 
9. Hayat, S.; Hayat, Q.; Alyemeni, M.N.; Wani, A.S.; Pichtel, J.; Ahmad, A. Role of Proline under Changing Environments: A Review. Plant Signal. Behav. 2012, 7, 1456-1466. [CrossRef]

10. Siddiqui, M.H.; Al-Whaibi, M.H.; Basalah, M.O. Role of Nitric Oxide in Tolerance of Plants to Abiotic Stress. Protoplasma 2011, 248, 447-455. [CrossRef] [PubMed]

11. Winter, G.; Todd, C.D.; Trovato, M.; Forlani, G.; Funck, D. Physiological Implications of Arginine Metabolism in Plants. Front. Plant Sci. 2015, 6, 1-14. [CrossRef] [PubMed]

12. Smith, T.A. Polyamines. Annu. Rev. Plant Physiol. 1985, 36, 117-143. [CrossRef]

13. El-Bassiouny HM, S.; Mostafa HA, M.; El-Khawas, S.A.; Hassanein, R.A.; Khalil, S.I.; Abd El-Monem, A.A. Physiological Responses of Wheat Plant to Foliar Treatments with Arginine or Putrescine. Aust. J. Basic Appl. Sci. 2008, 2, $1390-1403$.

14. Xia, J.; Yamaji, N.; Che, J.; Shen, R.F.; Ma, J.F. Normal Root Elongation Requires Arginine Produced by Argininosuccinate Lyase in Rice. Plant J. 2014, 78, 215-226. [CrossRef] [PubMed]

15. Duarte, M.D.R.; Hayashi, S.S. Estudo Anatômico de Folha e Caule de Pereskia Aculeata Mill.(Cactaceae). Rev. Bras. Farmacogn 2005, 15, 103-109. [CrossRef]

16. Hirner, A.; Ladwig, F.; Stransky, H.; Okumoto, S.; Keinath, M.; Harms, A.; Frommer, W.B.; Koch, W. Arabidopsis LHT1 Is a High-Affinity Transporter for Cellular Amino Acid Uptake in Both Root Epidermis and Leaf Mesophyll. Plant Cell 2006, 18, 1931-1946. [CrossRef]

17. Gazola, D.; Zucareli, C.; Silva, R.R.; Fonseca, I.C.D.B. Aplicação Foliar de Aminoácidos e Adubação Nitrogenada de Cobertura Na Cultura Do Milho Safrinha. Rev. Bras. Eng. Agrícola Ambient. 2014, 18, 700-707. [CrossRef]

18. Lima, M.D.G.D.S.; Mendes, C.R.; Nascimento, R.; Lopes, N.F.; Carvalho MA, P. Avaliação Bioquímica de Plantas de Milho Pulverizadas Com Uréia Isolada e Em Associação Com Aminoácidos. Rev. Ceres 2009, 56, 358-363.

19. Mógor, Á.F.; Ono, E.O.; Rodrigues, J.D.; Mógor, G. Aplicação Foliar de Extrato de Alga, Ácido L-Glutâmico e Cálcio Em Feijoeiro. Sci. Agrar. 2008, 9, 431-437. [CrossRef]

20. Civiero, J.C.; Daros, E.; Fiori-Tutida, A.C.; Alves, M.J.; Figueiredo, G.G. Crescimento Inicial Da Cana-de-Açucar Em Função Do Tamanho Do Mini-Reboleo Da Aplicação de Bioestimulantes. Rev. Bras. Tecnol. Appl. Nas Ciências Agrárias 2016, 9, 7-15. [CrossRef]

21. Lambais, G.R. Aminoácidos Como Coadjuvantes da Adubação Foliar e do Uso do Glifosato na Cultura de Soja; ESALQ/USP: Piracicaba, Brazil, 2011.

22. Bettoni, M.B.; Fabbrin, E.G.D.S.; Procopiuk, M.; Mógor, A.F. Crescimento de Mudas de Orégano Submetidas a Doses e Frequências de Aplicação de Ácido L-Glutâmico Em Sistema Orgânico. Rev. Bras. Plantas Med. 2014, 16, 83-88. [CrossRef]

23. Jiménez-Arias, D.; García-Machado, F.J.; Morales-Sierra, S.; Luis, J.C.; Suarez, E.; Hernández, M.; Valdés, F.; Borges, A.A. Lettuce Plants Treated with L-Pyroglutamic Acid Increase Yield under Water Deficit Stress. Environ. Exp. Bot. 2019, 158, $215-222$. [CrossRef]

24. Tsouvaltzis, P.; Koukounaras, A.; Siomos, A.S. Application of Amino Acids Improves Lettuce Crop Uniformity and Inhibits Nitrate Accumulation Induced by the Supplemental Inorganic Nitrogen Fertilization. Int. J. Agric. Biol. 2014, 16, 951-955.

25. Matysiak, K.; Kierzek, R.; Siatkowski, I.; Kowalska, J.; Krawczyk, R. Effect of Exogenous Application of Amino Acids L-Arginine and Glycine on Maize under Temperature Stress. Agronomy 2020, 10, 769. [CrossRef]

26. Kraus, T.E.; McKersie, B.D.; Fletcher, R.A. Paclobutrazol-Induced Tolerance of Wheat Leaves to Paraquat May Involve Increased Antioxidant Enzyme Activity. J. Plant Physiol. 1995, 145, 570-576. [CrossRef]

27. Azevedo, R.A.; Alas, R.M.; Smith, R.J.; Lea, P.J. Response of Antioxidant Enzymes to Transfer from Elevated Carbon Dioxide to Air and Ozone Fumigation, in the Leaves and Roots of Wild-Type and a Catalase-Deficient Mutant of Barley. Physiol. Plant. 1998, 104, 280-292. [CrossRef]

28. Giannopolitis, C.N.; Ries, S.K. Superoxide Dismutases: I. Occurrence in Higher Plants. Plant Physiol. 1977, 59, 309-314. [CrossRef] [PubMed]

29. Nakano, Y.; Asada, K. Hydrogen Peroxide Is Scavenged by Ascorbate-Specific Peroxidase in Spinach Chloroplasts. Plant Cell Physiol. 1981, 22, 867-880.

30. Alexieva, V.; Sergiev, I.; Mapelli, S.; Karanov, E. The Effect of Drought and Ultraviolet Radiation on Growth and Stress Markers in Pea and Wheat. Plant Cell Environ. 2001, 24, 1337-1344. [CrossRef]

31. Heath, R.L.; Packer, L. Photoperoxidation in Isolated Chloroplasts. Arch. Biochem. Biophys. 1968, 125, 189-198. [CrossRef]

32. Lichtenhaler, H.K.; Wellburn, A.R. Determinations of Total Carotenoids and Chlorophylls a and b of Leaf Extracts in Different Solvents. Biochem. Soc. Trans. 1983, 11, 591-592. [CrossRef]

33. AOAC. Oficial Methods of Analysis, 17th ed.; The Association of Official Analytical Chemists: Gaithersburg, MD, USA, 2000.

34. Hasanuzzaman, M.; Bhuyan MH, M.; Zulfiqar, F.; Raza, A.; Mohsin, S.M.; Mahmud, J.A.l.; Fujita, M.; Fotopoulos, V. Reactive Oxygen Species and Antioxidant Defense in Plants under Abiotic Stress: Revisiting the Crucial Role of a Universal Defense Regulator. Antioxidants 2020, 9, 681. [CrossRef] [PubMed]

35. Hasanuzzaman, M.; Nahar, K.; Rahman, A.; Inafuku, M.; Oku, H.; Fujita, M. Exogenous Nitric Oxide Donor and Arginine Provide Protection against Short-Term Drought Stress in Wheat Seedlings. Physiol. Mol. Biol. Plants 2018, 24, 993-1004. [CrossRef] [PubMed]

36. Nasibi, F.; Yaghoobi, M.M.; Kalantari, K.M. Effect of Exogenous Arginine on Alleviation of Oxidative Damage in Tomato Plant Underwater Stress. J. Plant Interact. 2011, 6, 291-296. [CrossRef] 
37. Tapiero, H.; Mathé, G.; Couvreur, P.; Tew KD, I. Arginine. Biomed. Pharmacother. 2002, 56, 439-445. [CrossRef]

38. Corpas, F.J.; Barroso, J.B.; Carreras, A.; Valderrama, R.; Palma, J.M.; León, A.M.; Sandalio, L.M.; Del Río, L.A. Constitutive Arginine-Dependent Nitric Oxide Synthase Activity in Different Organs of Pea Seedlings during Plant Development. Planta 2006, 224, 246-254. [CrossRef] [PubMed]

39. Sung, C.H.; Hong, J.K. Sodium Nitroprusside Mediates Seedling Development and Attenuation of Oxidative Stresses in Chinese Cabbage. Plant Biotechnol. Rep. 2010, 4, 243-251. [CrossRef]

40. Sadak, M.S.; Abdelhamid, M.T.; Schmidhalter, U. Efecto de La Aplicación Foliar de Aminoácidos Sobre El Rendimiento y Parámetros Fisiológicos En Plantas de Haba Irrigadas Con Agua de Mar. Acta Biol. Colomb. 2015, 20, 141-152. [CrossRef]

41. Yang, Z.; Mhamdi, A.; Noctor, G. Analysis of Catalase Mutants Underscores the Essential Role of CATALASE2 for Plant Growth and Day Length-Dependent Oxidative Signalling. Plant. Cell Environ. 2019, 42, 688-700. [CrossRef]

42. Su, T.; Wang, P.; Li, H.; Zhao, Y.; Lu, Y.; Dai, P.; Ren, T.; Wang, X.; Li, X.; Shao, Q.; et al. The Arabidopsis Catalase Triple Mutant Reveals Important Roles of Catalases and Peroxisome-Derived Signaling in Plant Development. J. Integr. Plant Biol. 2018, 60, 591-607. [CrossRef]

43. Mhamdi, A.; Queval, G.; Chaouch, S.; Vanderauwera, S.; Van Breusegem, F.; Noctor, G. Catalase Function in Plants: A Focus on Arabidopsis Mutants as Stress-Mimic Models. J. Exp. Bot. 2010, 61, 4197-4220. [CrossRef]

44. Palma, J.M.; Mateos, R.M.; López-Jaramillo, J.; Rodríguez-Ruiz, M.; González-Gordo, S.; Lechuga-Sancho, A.M.; Corpas, F.J. Plant Catalases as NO and H2S Targets. Redox Biol. 2020, 34, 101525. [CrossRef]

45. Tiburcio, A.F.; Kaur-Sawhney, R.; Galston, A.W. Polyamine Metabolism. Biochem. Plants 1990, 16, $283-325$.

46. Slocum, R.D. Genes, Enzymes and Regulation of Arginine Biosynthesis in Plants. Plant Physiol. Biochem. 2005, 43, 729-745. [CrossRef] [PubMed]

47. Tian, J.; Wang, L.P.; Yang, Y.J.; Sun, J.; Guo, S.R. Exogenous Spermidine Alleviates the Oxidative Damage in Cucumber Seedlings Subjected to High Temperatures. J. Am. Soc. Hortic. Sci. 2012, 137, 11-19. [CrossRef]

48. Li, Y.; Xu, X.; Lei, B.; Zhuang, J.; Zhang, X.; Hu, C.; Cui, J.; Liu, Y. Magnesium-Nitrogen Co-Doped Carbon Dots Enhance Plant Growth through Multifunctional Regulation in Photosynthesis. Chem. Eng. J. 2021, 422, 130114. [CrossRef]

49. Ahmed, A.M.A.; El-Gohary, A.E.; Osman, S.A.; Khalid, K.A. Arginine and Salinity Stress Affect Morphology and Metabolism of Indian Borage (Plectranthus Amboinicus Lour.). Shengtai Xuebao Acta Ecol. Sin. 2020, 40, 417-424. [CrossRef]

50. Rodriguez-Concepcion, M.; Avalos, J.; Bonet, M.L.; Boronat, A.; Gomez-Gomez, L.; Hornero-Mendez, D.; Limon, M.C.; MeléndezMartínez, A.J.; Olmedilla-Alonso, B.; Palou, A.; et al. A Global Perspective on Carotenoids: Metabolism, Biotechnology, and Benefits for Nutrition and Health. Prog. Lipid Res. 2018, 70, 62-93. [CrossRef]

51. Botrel, N.; Godoy, R.L.D.O.; Madeira, N.R.; Amaro, G.B.; Castro e Melo, R.A. Estudo Comparativo da Composição Proteica e do Perfil de Aminoácidos em Cinco Clones de Ora-pro-Nóbis; Embrapa Hortaliças: Brasília, Brazil, 2019.

52. Souza, M.R.D.M.; Pereira PR, G.; Magalhães, I.D.P.B.; Sediyama MA, N.; Vidigal, S.M.; Milagres CS, F.; Baracat-Pereira, M.C. Mineral, Protein and Nitrate Contents in Leaves of Pereskia Aculeata Subjected to Nitrogen Fertilization. Pesqui. Agropecuária Trop. 2016, 46, 43-50. [CrossRef] 